\title{
Pola resistensi Staphylococcus koagulase positif yang diisolasi dari burung lovebird terhadap beberapa antibiotik
}

\author{
Anggia Murni Wijiati ${ }^{1}$, Usamah Afiff ${ }^{2, *}$, Aulia Andi Mustika ${ }^{3}$ \\ ${ }^{1}$ Program Sarjana Fakultas Kedokteran Hewan, Institut Pertanian Bogor, Bogor \\ ${ }^{2}$ Divisi Mikrobiologi Medik, Departemen Ilmu Penyakit Hewan dan Kesehatan Masyarakat Veteriner \\ Fakultas Kedokteran Hewan, Institut Pertanian Bogor, Bogor \\ ${ }^{3}$ Divisi Farmakologi dan Toksikologi, Departemen Anatomi, Fisiologi dan Farmakologi, Fakultas Kedokteran Hewan, \\ Institut Pertanian Bogor, Bogor
}

\begin{abstract}
ABSTRAK: Informasi dan pengetahuan masyarakat yang masih minim mengenai antibiotik burung hias dapat menimbulkan penyalahgunaan dan resistensi antibiotik. Staphylococcus koagulase positif merupakan salah satu bakteri Gram positif yang bersifat patogen dan dapat menginfeksi burung lovebird. Tujuan penelitian ini adalah mengetahui resistensi Staphylococcus koagulase positif yang diisolasi dari swab kloaka burung lovebird terhadap beberapa antibiotik yang berbeda. Isolat bakteri yang digunakan sebanyak empat buah dan diuji terhadap antibiotik gentamisin, eritromisin, siprofloksasin, tetrasiklin, dan doksisiklin menggunakan metode difusi cakram menurut Kirby-Bauer. Interpretasi hasil dan penentuan sifat kepekaan mengacu pada Clinical and Laboratory Standards Institute (CLSI 2018). Hasil uji resistensi yang didapatkan bervariasi. Sifat resistensi hanya didapatkan terhadap gentamisin pada isolat 4. Intermediet didapatkan terhadap gentamisin pada isolat 1, serta terhadap eritromisin dan siprofloksasin pada isolat 4. Isolat 2 dan 3 menunjukkan kepekaan sensitif terhadap gentamisin, eritromisin, siprofloksasin, tetrasiklin, dan doksisiklin.
\end{abstract}

Kata kunci:

antibiotik, lovebird, resistensi, Staphylococcus koagulase positif

\section{- PENDAHULUAN}

Lovebird merupakan salah satu jenis burung hias yang digemari masyarakat untuk dipelihara. Hal yang perlu diperhatikan dalam pemeliharaan dan perkembangbiakan burung lovebird diantaranya pergantian musim, pemilihan pakan dengan nutrisi yang baik, serta kebersihan kandang. Flora normal Staphylococcus sp. merupakan salah satu agen yang menyebabkan pneumonia, endokarditis, abses, dan infeksi saluran pencernaan pada burung (Huttner et al. 2013).

Obat-obatan yang digunakan untuk mengatasi infeksi bakteri banyak tersedia dipasaran, namun penggunaannya tidak terkontrol dan dapat memicu terjadinya resistensi (Kazemnia et al. 2014). Penelitian ini bertujuan mengetahui resistensi Staphylococcus terhadap beberapa antibiotik dari swab kloaka burung lovebird.

\section{- MATERI DAN METODE}

Sampel yang digunakan berupa swab kloaka burung lovebird sebanyak 10 sampel, media isolasi dan identifikasi, cakram antibiotik gentamisin $10 \mu \mathrm{g}$, eritromisin $15 \mu \mathrm{g}$, siprofloksasin $5 \mu \mathrm{g}$, tetrasiklin $30 \mu \mathrm{g}$, dan doksisiklin $30 \mu \mathrm{g}$. Pengujian menggunakan metode difusi cakram menurut Kirby-Bauer. Interpretasi hasil dan penentuan kepekaan mengacu pada Clinical and Laboratory Standards Institute (CLSI 2018) (Tabel 1).
Tabel 1 Standar interpretasi diameter zona hambat Staphylococcus koagulase positif terhadap antibiotik (CLSI 2018)

\begin{tabular}{clcccc}
\hline \multirow{2}{*}{ No } & \multirow{2}{*}{ Antibiotik } & \multirow{2}{*}{ Dosis } & \multicolumn{4}{c}{ Diameter Zona Hambat (mm) } \\
\cline { 3 - 6 } & & & S & I & R \\
\hline 1 & Gentamisin & $10 \mu \mathrm{g}$ & $\geq 15$ & $13-14$ & $\leq 12$ \\
2 & Eritromisin & $15 \mu \mathrm{g}$ & $\geq 23$ & $14-22$ & $\leq 13$ \\
3 & Siprofloksasin & $5 \mu \mathrm{g}$ & $\geq 21$ & $16-20$ & $\leq 15$ \\
4 & Tetrasiklin & $30 \mu \mathrm{g}$ & $\geq 19$ & $15-18$ & $\leq 14$ \\
5 & Doksisiklin & $30 \mu \mathrm{g}$ & $\geq 16$ & $13-15$ & $\leq 12$ \\
\hline
\end{tabular}

Keterangan: I (Intermediet), R (Resisten), S (Sensitif)

\section{- HASIL DAN PEMBAHASAN}

Isolasi dan identifikasi 10 sampel swab kloaka didapatkan 4 isolat memiliki karakteristik sesuai dengan Staphylococcus koagulase positif. Sampel tersebut dilanjutkan dengan uji resistensi terhadap lima antibiotik. Hasil uji ditentukan dengan melakukan pengukuran diameter zona hambat yang terbentuk mengelilingi cakram antibiotik. Hasil uji resistensi sampel swab kloaka burung lovebird yang didapatkan kemudian disajikan pada Tabel 2.

Diterima: 16-01-2021 | Direvisi: 17-02-2021 | Disetujui: 21-02-202 (C) 2021 CC-BY-SA. Ini adalah artikel Open Access yang didistribusikan berdasarkan ketentuan dari Creative Commons Attribution ShareAlike 4.0 International License (https://creativecommons.org/licenses/by-sa/4.0/). 
Tabel 2 Hasil uji resistensi Staphylococcus koagulase positif terhadap antibiotik

\begin{tabular}{ccccccccc}
\hline \multirow{2}{*}{ Isolat } & \multicolumn{4}{c}{ Diameter Zona Hambat (mm) } & \multicolumn{3}{c}{ Jumlah } \\
\cline { 2 - 9 } & $\mathrm{CN}$ & $\mathrm{E}$ & $\mathrm{CIP}$ & $\mathrm{TE}$ & $\mathrm{DO}$ & $\mathrm{S}$ & $\mathrm{I}$ & $\mathrm{R}$ \\
\hline 1 & 14,0 & 25,6 & 22,0 & 25,0 & 29,0 & 4 & 1 & 0 \\
2 & 20,6 & 23,0 & 23,6 & 24,6 & 24,3 & 5 & 0 & 0 \\
3 & 21,6 & 24,0 & 25,3 & 23,6 & 20,0 & 5 & 0 & 0 \\
4 & 11,0 & 13,0 & 19,0 & 21,3 & 22,0 & 2 & 2 & 1 \\
\hline
\end{tabular}

Keterangan: $\quad$ CIP (Siprofloksasin), $\quad \mathrm{CN}$ (Gentamisin), $\quad$ DO (Doksisiklin), E (Eritromisin), I (Intermediet), R (Resisten), S (Sensitif), TE (Tetrasiklin)

Hasil pengujian antibiotik pada penelitian (Tabel 2) menunjukkan hasil sensitif terhadap kelima antibiotik yaitu pada isolat 2 dan 3 . Antibiotik tetrasiklin dan doksisiklin bersifat sensitif terhadap semua isolat bakteri. Hasil yang didapatkan berbeda dengan temuan Khusnan (2016) sebesar $21,7 \%$ pada sampel $S$. aureus yang diisolasi dari ayam broiler resistensi terhadap tetrasiklin dan $60,9 \%$ sampel resisten terhadap doksisiklin. Tetrasiklin dan doksisiklin merupakan antibiotik golongan tetrasiklin yang bekerja dengan melekat pada ribosom untuk menghambat sintesa protein bakteri serta menghambat interaksi antara mRNA dan tRNA sehingga menyebabkan berubahnya kode genetik dan terbentuk protein baru yang sifatnya nonfungsional (Soleha 2015).

Sifat kepekaan intermediet didapatkan pada dua isolat, yaitu terhadap gentamisin pada isolat 1 serta terhadap eritromisin dan siprofloksasin pada isolat 4. Hasil serupa terhadap eritromisin didapatkan pada $S$. aureus yang diisolasi dari daging ayam, dengan hasil intermediet $50 \%$ dari empat sampel terhadap eritromisin (Yurdakul et al. 2013). Kepekaan terhadap siprofloksasin pada penelitian ini sama dengan hasil yang didapat oleh Suleiman et al. (2013) Staphylococcus koagulase positif bersifat intermediet terhadap siprofloksasin. Eritromisin dan siprofloksasin bekerja dengan menghambat sintesa protein (Baharutan et al. 2015; Safitri et al. 2017). Penggunaan antibiotik intermediet sebaiknya dihindari dan digantikan dengan antibiotik yang efektivitasnya lebih baik karena dapat menyebabkan berkembangnya sifat resistensi bakteri tersebut (Krisnaningsih et al. 2005).

Hasil resisten didapatkan terhadap gentamisin pada isolat 4. Hal serupa didapatkan oleh Khusnan et al. (2016), yaitu $26 \%$ dari 23 isolat $S$. aureus yang diisolasi dari ayam broiler menunjukkan hasil resisten terhadap gentamisin. Gentamisin bekerja dengan berikatan pada subunit ribosom $30 \mathrm{~S}$ yang mengakibatkan ketidaksesuaian kodon dengan antikodon sehingga terjadi kegagalan pembentukan protein (Brooks et al. 2013). Mekanisme resistensi bakteri terhadap golongan aminoglikosida dapat berupa perubahan reseptor yaitu protein spesifik pada subunit 30S ribosom bakteri yang merupakan bagian sasaran antibiotik dan produksi enzim penginaktivasi aminoglikosida (Nurmala et al. 2015). Resistensi bakteri asal burung lovebird dapat terjadi karena adanya paparan bakteri resisten dari lingkungan, peralatan, ataupun organisme lain yang berkontak dengan burung (Wollhouse et al. 2015).

\section{SIMPULAN}

Kepekaan Staphylococcus koagulase positif yang diisolasi dari swab kloaka burung lovebird terhadap antibiotik pada penelitian ini bervariasi. Terdapat perbedaan pola resistensi terhadap gentamisin, eritromisin, dan siproflokasin dengan kepekaan yang tidak sensitif. Antibiotik tetrasiklin dan doksisiklin masih efektif untuk mengatasi infeksi Staphyococcus koagulase positif pada burung lovebird.

\section{- INFORMASI PENULIS}

Penulis Korespondensi

*UA: uafifff60@gmail.com

Divisi Mikrobiologi Medik, Departemen Ilmu Penyakit Hewan dan Kesehatan Masyarakat Veteriner, Fakultas Kedokteran Hewan, Institut Pertanian Bogor.

\section{- PUSTAKA ACUAN}

Baharutan KN, Fatimawali, Wullur A. 2015. Uji kepekaan bakteri yang diisolasi dari sputum pasien penderita bronkitis kronis yang menjalani rawat jalan di RSUP Prof. Dr. D Kandou Manado terhadap antibiotik ampisilin, eritromisin, dan siprofloksasin. Pharmachon. 4(4):139-146. Brooks GF, Carrollm KC, Butel JS, Murse SA, Mietzner TA. 2013. Jawetz, Melnick \& Adelberg's: Medical Microbiology. $26^{\text {th }}$ ed. New York (US): Mc-Graw Hill.

[CLSI] Clinical and Laboratory Standards Institute. 2018. Performance standards for antimicrobial susceptibility testing: 28th edition. West Valley (US): Clinical and Laboratory Standards Institute.

Huttner A, Harbarth S, Carlet J, Cosgrove S, Goossens H, Holmes A, Jarlier V, Voss A, Pittet D. 2013. Antimicrobial resistance: A global view from the 2013 world healthcare-associated infections forum. Antimicrobial Resistance and Infection Control. 2:31.

Kazemnia A, Ahmadi M, Dilmaghani M. 2014. Antibiotic resistance pattern of different Escherichia coli phylogenetic groups isolated from human urinary tract infection and avian colibacillosis. Iranian Biomedical Journal. 18(4):219-224.

Khusnan, Kusmanto D, Slipranata M. 2016. Resistensi antibiotik dan deteksi gen pengode Methicillin Resistant Staphylococcus aureus (MRSA) isolat broiler di wilayah Yogyakarta. Jurnal Kedokteran Hewan - Indonesian Journal of Veterinary Sciences. 10(1): 13-18.

Krisnaningsih MM, Wida A, Wibowo MH. 2005. Uji sensitivitas isolat Escherichia coli pathogen pada ayam terhadap beberapa jenis antibiotik. Jurnal Sain Veteriner. 1:13-18.

Nurmala, Virgiandhy IGN, Andriani, Liana DF. 2015. Resistensi dan sensi-tivitas bakteri terhadap antibiotik di RSU dr. Soedarso Pontianak tahun 2011-2013. eJournal Kedokteran Indonesia. 3(1): 21-28.

Safitri Y, Rohmi, Gede LS. 2017. Identifikasi jenis sampel (bakteri murni dan campuran bakteri) penyebab ISK terhadap hasil uji sensitivitas antibiotik siprofloksasin. Jurnal Analis Medika Biosains. 4(1): 12-16.

Soleha TU. 2015. Uji kepekaan antibiotik. JuKe Unila. 5(9):119-123.

Suleiman A, Zaria LT, Grema HA, Ahmadu P. 2013. Antimicrobial resistant coagulase positive Staphylococcus aureus from chickens in Maiduguri, Nigeria. Sokoto Journal of Veterinary Science. 11(1): 5155 .

Woolhouse M, Ward M, Bunnik BV, Farrar J. 2015. Antimicrobial resistance in humans, livestock, and the wider environment. Philosophical Transactions of The Royal Society Biological Sciences. 370:1-7.

Yurdakul NE, Erginkaya Z, and Unal E. 2013. Antibiotic resistance of enterococci, coagulase negative Staphylococci and Staphylococcus aureus isolated from chicken meat. Czech Journal of Food Science. 31(1):14-19. 